\title{
DIRECT FACTOR XA INHIBITOR IN THE PREVENTION OF THROMBOEMBOLISM
}

\section{BEZPOŚREDNIE WPROWADZENIE INHIBITORU CZYNNIKA XA W ZAPOBIEGANIU ŻYLNEJ CHOROBY ZAKRZEPOWO-ZATOROWEJ}

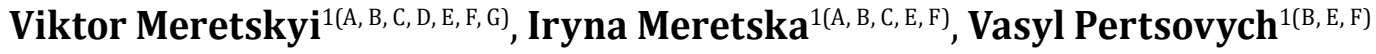 \\ ${ }^{1}$ Ivan Horbachevsky Ternopil State Medical University, Ukraine
}

Authors' contribution Wkład autorów: A. Study design/planning zaplanowanie badań B. Data collection/entry zebranie danych C. Data analysis/statistics dane - analiza i statystyki D. Data interpretation interpretacja danych E. Preparation of manuscript przygotowanie artykułu F. Literature analysis/search wyszukiwanie i analiza literatury G. Funds collection zebranie funduszy

Tables: 2

Figures: 1

References: 32

Submitted: 2018 Apr 25

Accepted: 2018 Jun 26

\section{Summary}

Venous thromboembolism is the third most common cause of vascular death after myocardial infarction and stroke, and is associated with considerable morbidity and premature mortality. The incidence of the most serious consequence of venous thromboembolism, fatal pulmonary embolism, ranges from $0.01 \%$ to $5 \%$ among hospitalised medical patients with multiple risk factors, and is currently considered the commonest avoidable cause of hospital death. Rivaroxaban is a small-molecule factor Xa inhibitor that belongs to a new class of direct oral anticoagulant agents that directly inhibit single enzymes in the coagulation pathway. Rivaroxaban has many advantages over vitamin $\mathrm{K}$ antagonists and unfractionated heparin and may become an alternative to traditional anticoagulant agents in patients at risk for thromboembolism. Moreover, antidotes exist and are in the progress of development, both specific and non-specific, for the treatment of overdose or side effects, including bleeding.

Keywords: venous thromboembolism, anticoagulants, rivaroxaban

\section{Streszczenie}

Żylna choroba zakrzepowo-zatorowa jest trzecią najczęstszą przyczyną śmierci naczyniowej tuż po zawale mięśnia sercowego i udarze mózgu, związana jest także z dużą zachorowalnością i przedwczesną umieralnością. Najpoważniejsze konsekwencje żylnej choroby zakrzepowozatorowej oraz śmiertelnej zatorowości płucnej wystepuja w przedziale od $0,01 \%$ do $5 \%$ wśród hospitalizowanych pacjentów medycznych, u których stwierdzono wiele czynników ryzyka i sa obecnie uważane za najczęstszą możliwa do uniknięcia przyczynę śmierci szpitalnej. Rivaroxaban jest drobnocząsteczkowym inhibitorem czynnika Xa, który należy do nowych bezpośrednich doustnych środków przeciwzakrzepowych, które bezpośrednio hamują pojedyncze enzymy w szlaku krzepnięcia. Rivaroksaban charakteryzuje się wieloma zaletami $\mathrm{w}$ porównaniu $\mathrm{z}$ antagonistami witaminy $\mathrm{K}$ i niefrakcjonowaną heparyną i może stać się alternatywą dla tradycyjnych leków przeciwzakrzepowych u pacjentów zagrożonych chorobą zakrzepowo-zatorową. Ponadto istnieją antidota (niektóre są w procesie rozwoju), zarówno swoiste, jak i nieswoiste, stosowane w celu leczenia przedawkowania lub działań niepożądanych, w tym krwawienia.

Słowa kluczowe: żylna choroba zakrzepowo-zatorowa, leki przeciwzakrzepowe, rywaroksaban 


\section{Introduction}

Venous thromboembolism (VTE), including pulmonary embolism (PE) and deep vein thrombosis (DVT), is considered to be the third most likely cause of vascular death after stroke and myocardial infarction. According to various sources, it is associated with considerable morbidity and premature mortality [1, 2]. Interestingly, VTE is 100 times more frequent among hospitalised patients compared to the general population, and an objectively diagnosed DVT can be detected in up to $80 \%$ of high-risk surgical and medical patients who are not on thromboprophylaxis. The incidence of the most dangerous consequence of VTE, which is fatal PE, ranges from $0.01 \%$ (low-risk surgical patients) up to 5\% (hospitalised medical patients with multiple risk factors). Pulmonary embolism is currently considered by the general public as the most common but avoidable cause of death in a hospital. In addition, VTE is often associated with long-term clinically significant complications, including post-thrombotic syndrome, chronic pulmonary hypertension, among others $[3,4,5,6]$.

The mainstay of VTE treatment is anticoagulation [1]. Many traditional anticoagulant agents including vitamin K antagonists, low molecular weight heparins, unfractionated heparin (UFH), and fondaparinux are widely available and used for the prevention and treatment of thromboembolic diseases. However, these agents have several limitations, including the requirement for regular coagulation monitoring (VKAs and UFH) and the need for parenteral administration (fondaparinux, UFH, low molecular weight heparin) and multiple interactions with other drugs and with food. To overcome some of these challenges, researchers developed a new class of anticoagulant drugs with comparable efficacy to existing agents, but with improved ease of use (for example: oral administration and no need for laboratory monitoring) [3]. In addition, the new direct oral anticoagulant agents (DOACs) as a class are associated with significantly less intracranial haemorrhage than warfarin, thus mitigating the most feared complication of anticoagulation treatment. These data support the need to develop target-specific oral anticoagulants which can directly inhibit coagulation pathway through single enzymes, such as Factor Xa or thrombin [7, 8, 9].

Rivaroxaban is approved for the treatment of deep venous thrombosis, pulmonary embolism. In addition, it is approved for the prevention of recurrent DVT/PE, stroke, systemic embolism in patients with non-valvular atrial fibrillation (AF), who have one or more risk factors, in combination with antiplatelet agents, for the prevention of atherothrombotic events following acute coronary syndrome (ACS) in patients with elevated levels of cardiac biomarkers. Each of these therapeutic indications has a specific regimen with different dosing, administration frequencies, and treatment durations $[7,10,11,12,13]$.

\section{Pharmacological Properties}

Rivaroxaban (scientific name 5-chloro-N-[[(5S)-2-oxo-3-[4-(3-oxomorpholin-4-yl)phenyl]-1,3-oxazolidin5-yl]methyl]thiophene-2-carboxamide) is considered a small-molecule factor Xa inhibitor due to its molecular weight, $436 \mathrm{~g} / \mathrm{mol}$. Rivaroxaban is slightly soluble in several organic solvents and is practically insoluble in polar solvents, such as water.

\section{In Vitro Studies}

\section{Factor Xa Inhibition}

Rivaroxaban works through the inhibition of factor $\mathrm{Xa}$ in a concentration-dependent manner. It is a competitive inhibitor for the amidolytic activity associated with factor Xa (Fig. 1). It has a rapid onset of action and is reversible. Factor $\mathrm{Xa}$ is essential for blood coagulation and is activated by both the extrinsic and intrinsic coagulation pathways. Factor Xa transforms prothrombin into thrombin through the prothrombinase complex, resulting in fibrin clot formation and activation of the platelets by thrombin $[14,15]$.

Rivaroxaban is selective for human factor Xa, for which it possesses $>10000$-fold greater selectivity compared to other biologically similar serine proteases. Factor Xa inhibition is species-dependent, and this has been demonstrated for a number of factor Xa inhibitors. Rivaroxaban has a similar affinity to purified human and rabbit factor Xa, but a lower affinity to rat factor Xa.

\section{Inhibition of Thrombin Formation}

In vitro studies using platelet-poor or platelet-rich plasma demonstrated that rivaroxaban prolonged the initiation phase of generation of thrombin and reduced the thrombin burst during the propagation phase. 
Rivaroxaban inhibited thrombin generation in human plasma obtained from healthy volunteers through the inhibition of factor Xa (intrinsic and extrinsic coagulation pathways).

\section{Plasma Clotting Times}

Rivaroxaban has satisfactory anticoagulant effects in human plasma. The drug prolonged prothrombin time (PT), activated partial thromboplastin time in a concentration-dependent manner. The sensitivity for PT was greater. Meanwhile, prolongation of clotting time differed depending on the PT or activated partial thromboplastin time reagent used. This is because rivaroxaban reactivity in the clotting assays was influenced by the composition of reagents. This variation cannot be reduced through the conversion of PT values calculated in seconds to internationally recognized, normalized ratio values. Therefore, in our opinion, PT and activated partial thromboplastin times are not very useful for the measurement of the pharmacodynamic effects of rivaroxaban.

\section{Thrombin-Thrombomodulin-Activated Protein C System}

The coagulation pathway has negative and positive feedback reactions in order to regulate haemostasis, and anticoagulants at therapeutic doses, in ideal conditions, should not influence negative feedback mechanisms, which are important in downregulating coagulation. One of the negative feedback mechanisms is the thrombinthrombomodulin-activated protein $\mathrm{C}$ system, which usually limits further generation of thrombin by inhibiting both factor Va and factor VIIIa. "In vitro" investigations of human plasma from healthy people or protein C-deficient plasma, factor Xa inhibitors, such as rivaroxaban, suppressed thrombin generation, depending on concentration, after stimulation by tissue factor and in the presence or absence of the thrombomodulin. This means that rivaroxaban does not significantly influence thrombin-thrombomodulin-activated protein $\mathrm{C}$ system.

\section{Platelet Aggregation}

Rivaroxaban does not influence collagen induced platelet aggregation, or that induced by adenosine diphosphate, the selective agonist of prostaglandin $\mathrm{H} 2$ /thromboxane $\mathrm{A} 2$ receptor U46619, or platelet aggregation induced by thrombin. However, rivaroxaban effectively inhibits tissue factor-induced platelet aggregation through the inhibition of thrombin generation in the case of defibrinated plasma. In addition to the anticoagulant effects of factor Xa inhibitor, this effect on aggregation of platelets may be particularly useful for the prevention or treatment of arterial thrombosis [14].

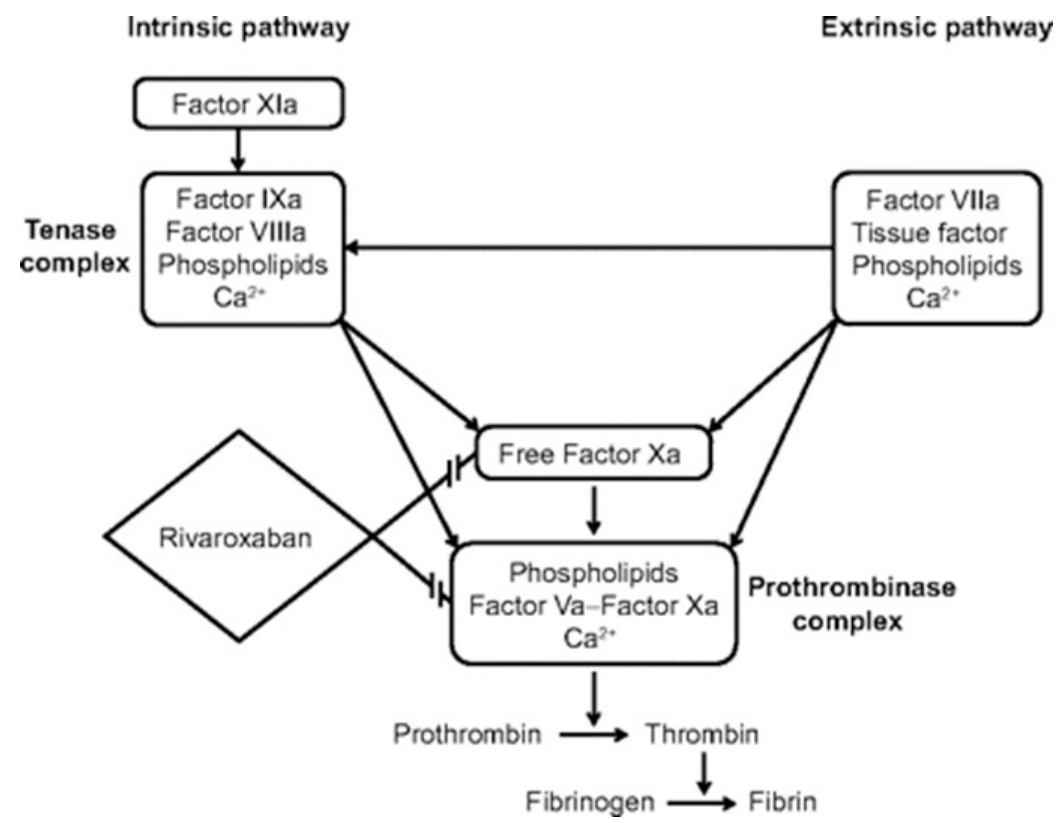

Figure 1. Factor Xa role in the coagulation cascade. Tissue factor/factor VIIa activates factor X and factor IX. Factor IXa activates factor X. Factor Xa binds factor Va, but on membrane surfaces. The prothrombinase and tenase both trigger the amplified thrombin formation. Rivaroxaban inhibits factor Xa, either free or within the prothrombinase [14] 


\section{In Vivo Studies and Dosing}

Rivaroxaban reduced thrombus formation in venous thrombosis models (including fibrin-rich and plateletpoor), where a combination of injection of tissue factor and stasis was used to induce formation of thrombus.

The substance showed sufficient dose-dependent activity against thrombus in arterial (fibrin-poor and platelet-rich) thrombosis models, including arteriovenous shunt model using rats and rabbits, as well as ferric chloride model (rats and mice). These results were consistent with the role of this coagulation system in thrombus formation in arteria.

The rivaroxaban anti-haemostatic effect was studied in well-characterized bleeding models in rats (tail transection bleeding time model), as well as rabbits (ear-bleeding time model). Bleeding times were not affected at antithrombotic doses below ED50, which are required for antithrombotic efficacy in the bleeding time models. Moreover, while using higher doses (rat tail-bleeding time model), the bleeding times were prolonged in a dosedependent manner. Therefore, considering antithrombotic results, these data show that rivaroxaban may have a favourable efficacy-to-bleeding ratio [14].

Rivaroxaban has oral bioavailability of $80-100 \%$ at the $10 \mathrm{mg}$ dose, irrespective of food intake. Under well fed conditions, $10 \mathrm{mg}, 15 \mathrm{mg}$ and $20 \mathrm{mg}$ tablets of rivaroxaban showed dose-proportional bioavailability. In a fasted state, rivaroxaban pharmacokinetics are fairly linear (up to $15 \mathrm{mg}$ once daily). In addition, oral bioavailability is reduced to $66 \%$ after a $20 \mathrm{mg}$ tablet. Bioavailability decreases at higher doses due to poor solubility. Ingested food does not affect the area under concentration-time curve, nor the maximum plasma concentration (Cmax) of a $10 \mathrm{mg}$ dose. Rivaroxaban administered as an oral dose is absorbed rapidly, with Cmax occurring 2-4 hours after the tablet intake [4]. Plasma protein binding values vary between biological species (rats - 98.7\%; rabbits $76.6 \%$; and humans - $92 \%$ to $95 \%$ ). Serum albumin is the main circulating binding component $[15,16]$.

Removal of rivaroxaban from plasma occurs with a terminal half-life of 5 to 9 hours for young individuals and 11 to13 hours for elderly patients. Rivaroxaban is metabolized by several completely independent metabolic pathways, which involve different classes of enzymes. The substance has a dual mode of elimination. Approximately two-thirds of the dose undergoes metabolic degradation by CYP450-dependent (CYP3A4, 212) or CYP-independent mechanisms, half of which is eliminated renally, with the other half using the hepatobiliary route. The final one-third of the dose goes through direct renal excretion with no changes in chemical structure of the active substance, mainly via active renal secretion. The drug has no major actively circulating blood metabolites $[7,14,17,18]$.

Age, gender, body weight have not been shown to exert clinically significant effects on the pharmacokinetic or pharmacodynamic profiles of rivaroxaban $[14,18]$. The International Society on Thrombosis and Haemostasis suggests that direct oral anticoagulants should not be used in patients weighing one hundred kilograms or more, as there are very limited clinical data available for the patients with these weights. The available pharmacokinetic/pharmacodynamic data suggested that decreased drug exposures, shorter half-lives and reduced peak concentrations occurred with increasing weight, which in turn raised concerns about possibility of under-dosing [19]. In patients who have had mild (creatinine clearance 50 to $79 \mathrm{~mL} / \mathrm{min}$ ), moderate (creatinine clearance 30 to $49 \mathrm{~mL} / \mathrm{min}$ ), or severe (creatinine clearance more than $30 \mathrm{~mL} / \mathrm{min}$ ) impairment of renal function, the area under the plasma concentration curve was $44 \%, 52 \%$, and $64 \%$ higher, respectively, comparing to control subjects. In those cases, maximum plasma concentration was relatively unaffected. Among patients who suffered mild (Child-Pugh A) hepatic functional impairment, researchers found no clinically relevant differences regarding pharmacokinetics and pharmacodynamics of rivaroxaban. To summarize, these findings suggest that the drug can be used for individuals with varying physical characteristics (such as age, body weight, gender, mild to moderate impairment of renal function, and mild hepatic functional impairment) at the same fixed dose, without requirements for dose adjustment or required routine coagulation monitoring [14].

Rivaroxaban levels may be affected by inhibitors and inducers of the P-glycoprotein transport protein and CYP3A4 enzyme. Rivaroxaban is a substrate of CYP3A4/ 5, CYP2J2, and the P-glycoprotein and ATP-binding cassette G2 (ABCG2) transporters. Concomitant use should be avoided and alternative anticoagulants considered for strong double-action CYP3A4 and P-glycoprotein inducers (rifampin, carbamazepine, phenytoin, St. John's wort), which in turn can decrease rivaroxaban levels. Due to the potential for an increase in rivaroxaban effect, concomitant use should also be avoided and alternate anticoagulants considered when strong dual CYP3A4 and P-glycoprotein inhibitors (ketoconazole, itraconazole, HIV protease inhibitors, conivaptan) are used. For concomitant use of weak or moderate dual CYP3A4 and P-glycoprotein inhibitors (amiodarone, verapamil, diltiazem, erythromycin, chloramphenicol, cimetidine) in the presence of $\mathrm{CrCl} 15$ to $80 \mathrm{~mL} / \mathrm{minute}$, alternative anticoagulant use should be considered [17, 20]. Histamine H2-receptor antagonists, such as ranitidine (a CYP3A4 inhibitor), as well as the antacid aluminum-magnesium hydroxide, have no significant effect on the 
pharmacokinetics and pharmacodynamics of the rivaroxaban [14].

Rivaroxaban showed favourable safety and tolerance levels in healthy individuals [14]. However, it is advisable to avoid rivaroxaban in patients with a high risk of gastrointestinal tract bleeding, as some evidence exists about higher GI bleeding rates compared to warfarin.

Rivaroxaban should not be used in pregnancy and in females who are breast feeding. Moreover, women of child-bearing age should be advised appropriately [19].

Prior to beginning of treatment, a full blood count, baseline coagulation screen, urea and electrolytes (including renal function), and liver function tests should be performed. Table 1 gives guidance for the recommended doses of rivaroxaban [19].

Table 1. Dosing advices for rivaroxaban [19]

\begin{tabular}{|c|c|}
\hline & Rivaroxaban \\
\hline Standard Dose & $\begin{array}{l}\text { Days 1-21: } 15 \mathrm{mg} \text { bd orally (with food) } \\
\text { Day } 22 \text { and forward: } 20 \mathrm{mg} \text { od orally (with food) }\end{array}$ \\
\hline \multirow{2}{*}{ Renal impairment } & $\begin{array}{l}\text { Warfarin preferred if } \mathrm{CrCl} \text { less than } 30 \mathrm{ml} / \mathrm{min} \\
\text { Do not use the drug if } \mathrm{CrCl} \text { less than } 15 \mathrm{ml} / \mathrm{min}\end{array}$ \\
\hline & $\begin{array}{c}\text { Day } 22 \text { onwards (if } \mathrm{CrCl} 30-49 \mathrm{ml} / \mathrm{min} \text { ): consider reducing to } 15 \mathrm{mg} \text { od if the patient's } \\
\text { risk of bleeding outweighs the risk of recurrence }\end{array}$ \\
\hline $\begin{array}{l}\text { Hepatic impairment } \\
\text { and dysfunction }\end{array}$ & $\begin{array}{l}\text { Rivaroxaban is contraindicated for the patients with hepatic disease associated } \\
\text { with coagulopathy, clinically relevant bleeding risk including cirrhotic patients } \\
\text { with Child Pugh B and C }\end{array}$ \\
\hline Switching from dalteparin & Rivaroxaban should be used instead of the next scheduled dalteparin administration \\
\hline Switching to dalteparin & Give the first dose of dalteparin at the time when the next rivaroxaban dose is due \\
\hline Switching from warfarin & $\begin{array}{c}\text { Stop warfarin; start rivaroxaban once INR is } 2.5 \text { or less (do not forget about higher } \\
\text { initial dosing if within three weeks after an acute event) }\end{array}$ \\
\hline Switching to warfarin & Co-administer rivaroxaban and warfarin together until INR is 2 or higher \\
\hline
\end{tabular}

Patients who have proximal DVT or PE must be treated for three months or longer. In cases of the first proximal DVT or a PE associated with transient risk factors, the use of rivaroxaban will usually stop after three months. Long term treatment would be considered in case of recurrent thrombosis, or for the patients with ongoing risk factor, or those having unprovoked proximal DVT or PE. It might be feasible to decide on finite (such as three months duration) or indefinite anticoagulation after treatment has started, though many patients (for example, those with a first unprovoked proximal DVT or PE) would to be reviewed after three months in order to decide whether to stop anticoagulation treatment or maybe continue it indefinitely [19].

Patients must be informed about the risk of missing a rivaroxaban dose due to its rapid onset and offset of anticoagulant activity. Therefore, even one day without rivaroxaban will cause the patient to become unanticoagulated [21].

Rivaroxaban is used to prevent venous thromboembolism among adult patients undergoing elective hip or knee replacement surgery, treatment of DVT and PE, and to prevent recurrent DVT and PE among adult patients. Rivaroxaban showed superiority compared to standard therapy with enoxaparin in cases of orthopaedic surgery without significant increase in the major bleeding rate [14].

The duration of the therapy and dose should be determined on case by case basis after careful assessment of the treatment benefits comparing to the risks for bleeding (Table 2).

Table 2. The duration of therapy with rivaroxaban and dose selection

\begin{tabular}{|c|c|c|c|}
\hline & Time Period & Dosing schedule & Total daily dose \\
\hline \multirow{2}{*}{$\begin{array}{c}\text { Treatment and prevention } \\
\text { of recurrent DVT and PE }\end{array}$} & Day 1 to day 21 & $15 \mathrm{mg}$ twice daily & $30 \mathrm{mg}$ total \\
\cline { 2 - 4 } & Day 22 and forward & $20 \mathrm{mg}$ once daily & $10 \mathrm{mg}$ total \\
\hline $\begin{array}{c}\text { Prevention of recurrent } \\
\text { DVT and PE }\end{array}$ & $\begin{array}{c}\text { Following completion } \\
\text { of } 6 \text { months therapy } \\
\text { for DVT or PE }\end{array}$ & $\begin{array}{c}10 \mathrm{mg} \text { once daily or } 20 \mathrm{mg} \\
\text { once daily }\end{array}$ & 10 total \\
\hline
\end{tabular}


Rivaroxaban plus aspirin improves survival and reduces stroke and heart attack in patients with stable coronary or peripheral artery disease, according to late-breaking results from the COMPASS trial. Rivaroxaban, at both a treatment dose $(20 \mathrm{mg})$ and a thrombo-prophylactic dose $(10 \mathrm{mg})$, was more effective than aspirin in the prevention of recurrent venous thromboembolism among patients who were in equipoise for continued anticoagulation [1].

Since rivaroxaban is administered in fixed doses, routine measurement of the drug levels in plasma or its pharmacodynamic effects are notrequired or recommended. However, thereare certain clinical scenariosin which coagulation testing and measurement of drug levels are necessary, such as episodes of bleeding, peri-operative management, suspected over dosage either from drug interactions or intentional overdose, renal impairment or as a measure of suspected non-compliance [8]. The choice of the laboratory test for rivaroxaban levels will depend on the clinical situation. For example, if qualitative determination of the presence of rivaroxaban in the blood is needed, the PT test is appropriate, given that a rivaroxaban-sensitive reagent is used. On the other hand, if quantitative measurement of plasma rivaroxaban is needed, an anti-Factor XNA chromogenic assay together with rivaroxaban standard solutions and controls with results expressed as rivaroxaban concentration $(\mu \mathrm{g} / \mathrm{l})$ can give precise and accurate results. No matter which test is being used, interpretation of results must take into account the timing of blood sampling (considering pharmacokinetics of rivaroxaban), as well as differences in the functionality of the assays $[7,8,20]$.

\section{Rivaroxaban antidotes against overdose or bleeding}

Research conducted by Eikelboom J.W. et al. reported a favourable benefit-risk profile for the use of DOACs. However, they are still associated, as are any anticoagulants, with a significant risk of bleeding [22].

According to [23], one of the major drawbacks of direct oral anticoagulants compared to warfarin was absence of specific antidotes which can reverse the anticoagulant effect in case of emergencies, such as overdose due to the medical negligence or excessive bleeding. The same authors suggested that several non-specific substances can be administered in situations of DOACs overdoses, including frozen plasma, Prothrombin Complex Concentrate (PCC), or activated Prothrombin Complex Concentrate (PCC), recombinant activated factor VII, as well as haemodialysis and activated charcoal, but the bleeding cessation success was not quite rapid or obvious. It was suggested by J.W. Eikelboom et al. [22] that fresh frozen plasma cannot be used to negate the bleeding effect as large volumes are needed. Prothrombin complex concentrates (PCCs) are purified and viral inactivated concentrates of vitamin K-dependent coagulation factors, which are obtained from pooled normal plasma [24]. Even PCC, which has 25 times more blood clotting factors than frozen plasma, is associated with low, but not negligible, risk of thromboembolic adverse events. 3-factor and 4-factor PCCs are available on the market [24]. Some researchers noted a favourable outcome after 4-factor PCC administration in six of eighteen patients with intracranial haemorrhage who were treated with rivaroxaban or apixaban [25]. Activated PCC (aPCC), or factor VIII inhibitor bypassing agent (FEIBA, Baxter, Deerfield, IL, USA), was developed as one of the pro-haemostatic agents for the management of haemophiliacs. aPCC is a surface-activated PCC which contains small amounts of FIXa, FXa, as well as thrombin, and larger quantities of FVIIa. According to Vanden Daelen et al., aPCC corrected all thrombin generation factors in vitro in plasma obtained from healthy volunteers who were administered rivaroxaban, and reduced blood loss in animals after administration of rivaroxaban [26]. Recombinant activated factor VII (rFVIIa; NovoSeven, Novo Nordisk, Bagsvaerd, Denmark) is a recombinant protein developed originally to treat and prevent bleeding in patients with haemophilia with inhibitors to factor VIII or IX [27]. However, considering the significant thrombin generating burst induced by rFVIIa and the pre-existing thrombogenic diathesis, rFVIIa may only be considered as a last-resort option in case of life- or organ-threatening bleeding, especially regarding patients with acute ischaemia.

Several therapies which are aimed at reduction of drug exposure include rivaroxaban absorption reduction from gastrointestinal tract and rivaroxaban removal from the blood, using activated charcoal and haemodialysis, respectively. Activated charcoal is a physically and chemically processed form of carbon that can bind oral drugs, thus reducing their absorption from the intestines. Although activated charcoal proved to be useful in reducing absorption of dabigatran and apixaban [28, 29], we did not find any information regarding rivaroxaban. However, the use of activated charcoal to reduce absorption still might be considered in case of a recent overdose with rivaroxaban, using a standard dosing of 30-50 g for adults per intake [30]. Haemodialysis cannot remove rivaroxaban efficiently, as it is highly protein bound [31].

In our opinion, the best option for treating excessive bleeding caused by rivaroxaban administration in the future may be the use of targeted reversal agents.

Recently, a specific reversal agent against factor Xa inhibitors was developed, known as Andexanet alfa 
(PRT064445, AndexXa ${ }^{\circledR}$, Portola Pharmaceuticals, South San Francisco, CA, USA) [22]. Andexanet alfa is a modified human recombinant factor Xa which is catalytically inactive, though retains high-affinity binding to direct factor Xa inhibitors or heparin-antithrombin III complexes. Andexanet alfa induced complete reversal of either apixaban or rivaroxaban anticoagulant activity rapidly (approximately two minutes after administration), without any adverse effects in two recent completed parallel phase III trials - ANNEXA-A and ANNEXA-R. The phase four clinical trial (ANNEXA-4) is under way.

One more antidote was proposed, namely, aripazine (PER-977), which is thought to be an effective antidote against not only rivaroxaban, but also dabigatran, apixaban, subcutaneous fondaparinux and LMWH. It is also known as ciraparantag (Perosphere Pharmaceuticals, Danbury, CT, USA), and is a small, water-soluble, synthetic cationic molecule which reverses unfractionated heparin, low-molecular-weight heparin and fondaparinux using non-covalent hydrogen binding and charge-charge interactions. It is capable of DOACs inactivation through non-covalent hydrogen binding [32]. Ciraparantag (aripazine) was shown to reverse the anticoagulant effect of all DOACs in thrombo-elastographic studies and animal models.

\section{Conclusions}

1. The selective factor Xa inhibitor rivaroxaban belongs to a new class of anticoagulant drugs, which are designed to overcome the deficiencies of current deep vein thrombosis and pulmonary embolism therapies.

2. Rivaroxaban has many advantages over VKAs and UFH, including a rapid onset and cessation of anticoagulant effect, fixed dosing, fewer drug and dietary interactions and no monitoring requirement.

3. The pharmacodynamics and stable pharmacokinetic profiles, which were found to be predictable, together with the wide therapeutic window, enhance the likelihood that oral factor Xa inhibitors, including rivaroxaban, might become alternatives to vitamin Kantagonists, unfractionated heparin, and low molecular weight heparins for the patients with a risk of thromboembolism.

4. Effective antidotes exist and are in the progress of development for the treatment of rivaroxaban overdose or side effects, such as bleeding.

\section{References:}

1. Weitz JI, Lensing AWA, Prins MH, Bauersachs R, Beyer-Westendorf J, Bounameaux H, et al. Rivaroxaban or aspirin for extended treatment of venous thromboembolism. New England Journal of Medicine. 2017; 376 (13): 1211-22. https://doi.org/10.1056/NEJMoa1700518

2. Jun M, Lix LM, Durand M, Dahl M, Paterson JM, Dormuth CR, et al. Comparative safety of direct oral anticoagulants and warfarin in venous thromboembolism: multicenter, population based, observational study. BMJ. 2017; 359: j4323. https://doi.org/10.1136/bmj.j4323

3. Franchini M, Mannucci PM. Direct oral anticoagulants and venous thromboembolism. European Respiratory Review. 2016; 25: 295-302. https://doi.org/10.1183/16000617.0025-2016

4. Kearon C, Akl EA, Ornelas J, Blaivas A, Jimenez D, Bounameaux H, et al. Antithrombotic therapy for VTE disease: CHEST guideline and expert panel report. Chest. 2016; 149: 315-52. https://doi.org/10.1016/j.chest.2015.11.026

5. ISTH Steering Committee for World Thrombosis Day. Thrombosis: a major contributor to global disease burden. Thromb Res. 2014; 134: 931-8. https://doi.org/10.1016/j.thromres.2014.08.014

6. Keeling D, Tait RC, Watson H. British Committee of Standards for Haematology. Peri-operative management of anticoagulation and antiplatelet therapy. Br J Haematol. 2016; 175(4): 602-13. https://doi.org/10.1111/bjh.14344

7. Samama MM, Contant G, E Spiro T, Perzborn E, Le Flem L, Guinet C, et al. Laboratory assessment of rivaroxaban: a review. Thromb J. 2013; 11: 11. https://doi.org/10.1186/1477-9560-11-11

8. Lee LH. DOACs - advances and limitations in real world. Thromb J. 2016; 14(Suppl. 1): 17. https://doi.org/10.1186/s12959-016-0111-3

9. Savarese G, Giugliano RP, Rosano GM, McMurray J, Magnani G, Filippatos G, et al. Efficacy and safety of novel oral anticoagulants in patients with atrial fibrillation and heart failure: a meta-analysis. JACC Heart Fail. 2016; 4(11): 870-80. https://doi.org/10.1016/j.jchf.2016.07.012

10. Kubitza D, Berkowitz SD, Misselwitz F. Evidence-based development and rationale for once-daily rivaroxaban dosing regimens across multiple indications. Clinical and Applied Thrombosis/Hemostasis. 2016; 22(5): 412-22. https://doi.org/10.1177/1076029616631427

11. Camm AJ, Amarenco P, Haas S, Hess S, Kirchhof P, Kuhls S, et al. XANTUS: a real-world, prospective, 
observational study of patients treated with rivaroxaban for stroke prevention in atrial fibrillation. Eur Heart J. 2016; 37(14): 1145-53. https://doi.org/10.1093/eurheartj/ehv466

12. Noseworthy PA. Direct comparison of dabigatran, rivaroxaban, and apixaban for effectiveness and safety in nonvalvular atrial fibrillation. Chest. 2016; 150: 1302. https://doi.org/10.1016/j.chest.2016.07.013

13. Pan KL, Singer DE, Ovbiagele B, Wu YL, Ahmed MA, Lee MJ. Effects of non-vitamin K antagonist oral anticoagulants versus warfarin in patients with atrial fibrillation and valvular heart disease: a systematic review and meta-analysis. Am Heart Assoc. 2017; 6(7): e005835. https://doi.org/10.1161/JAHA.117.005835

14. Perzborn E, Roehrig S, Straub A, Kubitza D, Mueck W, Laux V. Rivaroxaban: a new oral factor Xa inhibitor. Arteriosclerosis, Thrombosis, and Vascular Biology. 2010; 30: 376-81. https://doi.org/10.1161/ATVBAHA.110.202978

15. Aguiar CCT. Treatment of depression in patients on anticoagulation therapy: antidepressant-rivaroxaban drug interactions. J Drug Metab Toxicol. 2016; 7: 215. https://doi.org/10.4172/2157-7609.1000215

16. Muster H, Alcorn JH. Rivaroxaban in chronic hemodialysis patients. Am J Nephrol. 2016; 43: 227-8. https://doi.org/10.1159/000445329

17. Olshansky B, Chung MK, Pogwizd SM, Goldschlager N. Arrhythmia essentials (second edition). Philadelphia: Elsevier; 2017.

18. Creager MA, Beckman JA, Loscalzo J. Vascular medicine: a companion to Braunwald's heart disease (second edition). Philadelphia: Elsevier; 2013.

19. Price V, Keelig D. Tratment of deep vein thrombosis (DVT) and pulmonary embolism (PE) with rivaroxaban or apixaban in adults. MIL. 2017; 8(1).

20. Siegal DM, Konkle BA. What is the effect of rivaroxaban on routine coagulation tests? ASH Education Book. 2014; 1: 334-6. https://doi.org/10.1182/asheducation-2014.1.334

21. Sikorska J, Uprichard J. Direct oral anticoagulants: a quick guide. European Cardiology Review. 2017; 12(1): 40-5. https://doi.org/10.15420/ecr.2017:11:2

22. Eikelboom JW, Kozek-Langenecker S, Exadaktylos A, Batorova A, Boda Z, Christory F, et al. Emergency care of patients receiving non-vitamin $\mathrm{K}$ antagonist oral anticoagulants. British Journal of Anaesthesia. 2018; 120(4): 645-56. https://doi.org/10.1016/j.bja.2017.11.082

23. Tummala R, Kavtaradze A, Gupta A, Ghosh RK. Specific antidotes against direct oral anticoagulants: a comprehensive review of clinical trials data. International Journal of Cardiology. 2016; 214: 292-8. https://doi.org/10.1016/j.ijcard.2016.03.056

24. Grottke O, LevyJH. Prothrombin complex concentrates in trauma and perioperative bleeding. Anesthesiology. 2015; 122: 923-31. https://doi.org/10.1097/ALN.0000000000000608

25. Grandhi R, Newman WC, Zhang X, Harrison G, Moran C, Okonkwo D, et al. Administration of 4-factor prothrombin complex concentrate as an antidote for intracranial bleeding in patients taking direct factor Xa inhibitors. World Neurosurg. 2015; 84: 1956-61. https://doi.org/10.1016/j.wneu.2015.08.042

26. Vanden Daelen S, Peetermans M, Vanassche T, Verhamme P, Vandermeulen E. Monitoring and reversal strategies for new oral anticoagulants. Expert Rev Cardiovasc Ther. 2015; 13: 95-103. https://doi.org/10.1586/14779072.2015.987126

27. Ragni MV. The old and new: PCCs, VIIa, and long-lasting clotting factors for hemophilia and other bleeding disorders. Hematol Am Soc Hematol Educ Program. 2013; 2013(1): 44-51. https://doi.org/10.1182/asheducation-2013.1.44

28. Wang X, Mondal S, Wang J, Tirucherai G, Zhang D, Boyd RA, et al. Effect of activated charcoal on apixaban pharmacokinetics in healthy subjects. Am J Cardiovasc Drugs. 2014; 14: 147-54. https://doi.org/10.1007/s40256-013-0055-y

29. Woo JS, Kapadia N, Phanco SE, Lynch CA. Positive outcome after intentional overdose of dabigatran. J Med Toxicol. 2013; 9: 192-5. https://doi.org/10.1007/s13181-012-0276-5

30. Heidbuchel H, Verhamme P, Alings M, Antz M, Diener H-Ch, Hacke W, et al. Updated European Heart Rhythm Association practical guide on the use of non-vitamin $\mathrm{K}$ antagonist anticoagulants in patients with nonvalvular atrial fibrillation. Europace. 2015; 17: 1467-507. https://doi.org/10.1093/europace/euv309

31. Siegal DM, Garcia DA, Crowther MA. How I treat target-specific oral anticoagulant-associated bleeding. Blood. 2014; 123: 1152-8. https://doi.org/10.1182/blood-2013-09-529784

32. Ansell JE, Bakhru SH, Laulicht BE, Steiner SS, Danbury P, Grosso M, et al. Use of PER977 to reverse the anticoagulant effect of edoxaban. N Engl J Med. 2014; 371: 2141-2. https://doi.org/10.1056/NEJMc1411800 